\section{CAN METHODOLOGICAL LIMITS BE SET IN THE DEBATE ON THE IDENTIFICATION OF 7Q5?}

\section{$\mathrm{M}^{\mathrm{a}}$ VICTORIA SPOTTORNO CSIC. Madrid}

The papyrus fragment 7Q5 has caused a polemic based on the fact that it has few recognisable letters, even fewer words, and a generally cloudy history. The polemic started when J. O'Callaghan identified 7 Q5 as Mark 6:52-53 in 1972, and has remained tenacious in his proclamation of the certainty of his identification since he first published it. ${ }^{1}$ He and his follower C.P. Thiede often move the debate to journals and reviews where the severe and rigorous objections of serious scholars do not appear. Lately, on the Internet, I came across an interview with O'Callaghan by G. Mckenzie González, ${ }^{2}$ in which O'Callaghan's personable and open expressiveness certainly did not hide his authoritarian arguments. He explains the history of the identification of 7Q5 with Mark 6:52 53, stressing the honesty and papyrological rigor observed by him throughout the process, and showing more eagerness to succeed in his thesis than the scientific interest needed to gain a valid conclusion. The reader can perceive that O'Callaghan does not pay enough attention to the actual meaning of the opposing arguments. ${ }^{3}$ Although he says that he seriously considers

${ }^{1}$ J. O'Callaghan, “¿Pápiros neotestamentarios en la cueva 7 de Qumrân?" Bib 53 (1972) $91-100$.

2 "Un papiro revolucionario: 7Q5," entrevista al P. José O'Callaghan, S.J., por Germán Mckenzie González, cortesía de la revista Vida y Espiritualidad, VE mayoagosto de 1995, año 11, n 31 ; versión electrónica realizada por VE Multimedios \& Trade (henceforth Internet).

3 "They [the opponents] attacked me vehemently, but they were personal attacks with great international repercussions, rather than scientific arguments. I could see, with the arguments allowed by the science of papyrology, with which I am acquainted, that they did not touch the core of the question. Their attacks had little papyrological scientific content. Then I began answering them rigorously, paying attention to the arguments and not to the persons... I thought I was wasting my time and energies in a debate that, planned in such terms, was worthless... As a papyrologist I consider pathetic their proposed alternatives. It seems that they wish to lead astray or to talk, other reconstructions of the text, ${ }^{4}$ he accepts only one possibility for the eight letters of the fragment..$^{5}$ All other possibilities are dismissed as impossibilities, because the identification of 705 with Mark 6:52-53 is the truth; ${ }^{6}$ and the truth is real, objective and conclusive. In my opinion, this a priori argument begs the question at hand and minimizes many relevant contributions to an open scientific debate on this subject. ${ }^{7}$

lternative proposals the most elementary scientific methodology has not been taken into account And I stand by these words" "Ellos me atacaban fuertemente, pero más que argumentos científicos de peso eran ataques personales de gran resonancia interque argumentos científicos de peso eran ataques personales de gran resonancia intera que conozco, que no tocaban el meollo de la cuestión. Eran ataques de poco contenido científico papirológico. Entonces empecé a responder con rigurosidad atendiendo a los argumentos y no a las personas... Pensaba que perdía tiempo y energías en un debate que planteado en esos términos no valía la pena... Esas alternancias que proponen, como papirólogo ... ¡da pena verlas! Parece que aquí quieren más que iluminar desorientar y hablar por hablar... Se ve que es evidente que en las propuestas de

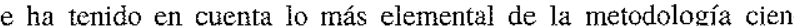
tífica. $\mathrm{Y}$ esto lo digo de manera absoluta"). And again: "Those alternative positions are disgraceful according to science" ("Estas significaciones alternativas que han propuesto en verdad dan pena en el plano científico. [Etc., etc.]") (Internet 3, 6).

4 "I analyse in depth all their papyrological statements" ("Todo lo que afirman a nivel papirológico yo lo analizo en profundidad"...) (Internet 5).

5 "There (in his book Los primeros testimonios del Nuevo Testamento. Papirología neotestamentaria [Córdoba: Ediciones El Almendro, 1995]) I declare and prove scientificlily from a papyrologic mine ... This mater is definitively proved and definitely certain, this Professor Dou has also confirmed from the point of view of mathematical possibilities" "Allí declaro y pruebo científicamente, desde un punto de vista papirológico que el 7Q5 es Mc 6,52 53 ... El asunto está decididamente probado y es decididamente seguro, cosa que también me ha dicho, desde el punto de vista de las posibilidades matemáticas, el mismo profesor Dou") (Internet 5).

6 "With the final results of my research, I am happy to have found this to be true... I am pleased to have proposed an identification that can be stated with $\mathrm{cer}$ tainty [emphasis mine]." "“Tras los resultados finales de la investigación estoy encantado de que esto haya sido verdad... estoy contento de que la identificación que propuse pueda afirmarse con certeza") (Internet 14, 15).

C.P. Thiede, whose papyrological and textual experience does not seem extensive (he is Director of the Institute for Basic Epistemological Research in Paderborn), has produced a great deal concerning this topic. He has advanced the dates of some manuscripts, against the criteria of eminent papyrologists as C.H. Roberts and P.J. Parsons, to enlarge the basis of O'Callaghan's proposal. Moreover he accepts and promotes the objection to his arguments; cf. S.R. Pickering, "Controversy Sur the Gospel of Matthew in Magdalen College, Oxford," New Testament Textual Research Update 3 (1995) 22-25; and É. Puech, "Des fragments grecs de la grotte 7 et le Nouveau Testament? 7Q4 et 7Q5, et le papyrus Magdalen grec $17=\mathrm{P}^{64}$," $R B 102$ (1995) 577-84; also the sound arguments adduced by D.D. Parker, "Was Matthew written before 50 CE? The Magdalen Papyrus of Matthew," ExpTim 107 (1996) 40-43, to which Thiede replies, pointing out "factual errors" in Parker's views 〈ExpTim 107 (1996) 240-41); as well as K. Wachtel, "p64/67: Fragmente des Matthäusevangeliums 
When I published a proposed alternative to O'Callaghan's identification in the journal Sefarad, ${ }^{8}$ it was not O'Callaghan who answered me, but C.P. Thiede. In his article "Greek Qumran Fragment 7Q5: Possibilities and Impossibilities," Thiede does not merely disagree with my hypothesis, but with condescension attacks my identification, which "is to be rejected as impossible for palaeographical as well as philological reasons." Again, it is this anti-scientific, anti-academic attitude that I oppose in this paper. I will go as far as to claim, based on philological, palaeographical and related evidence, that my alternative identifications for 7Q5 are more probable than O'Callaghan's or Thiede's identification, even if none of them can be definitively proven to be correct. ${ }^{11}$

\section{Palaeographic questions}

Difficulties have been thoroughly analysed by scholars, and recently E. Puech ${ }^{12}$ has studied the original in detail; although I generally accept his views, I would like to add some remarks.

Concerning isolated letters or incomplete words, it is important to remember that our eyes tend to see the proper letters in order to reconstruct a suitable word. ${ }^{13}$ The handwriting of our fragment shows moderate regularity with significant variations in the size and shape of the letters represented twice: the two $v$ in line 4 , the $\eta$ in lines 4 and

aus dem 1. Jahrhundert?" Zeitschrift für Papyrologie und Epigraphik 107 (1995) 73-80. 8 M.V. Spottorno, "Una nueva posible identificación de 7Q5," Sefarad 52 (1992) M.V. Spottorno, "Una nueva posible idention the IV Simposio bíblico español $541-43$, a short version of my contribution to the IV Simposio bíblico español Simposio bíblico español (I ibero-americano). Biblia y culturas (eds J.R. Ayaso Martínez et al.; Valencia-Granada: Universidad de Granada, 1993) 1.333-39.

${ }^{9}$ Bib 75 (1994) 394-98.

10 Thiede, "Greek Qumran Fragment," 398. Thiede's own palaeographical or philological resons are not clearly indicated, since his argumentation is roughly, that every logical reasons are no clearly ind "impossible ... highly reading that does not coincide with .O 'Callaghan's is therefore "Impossble... highly unlikely ... hardly possible."

${ }^{11}$ See S.R. Pickering, "Looking for Mark's Gospel among the Dead Sea Scrolls: The Continuing Problem of Qumran Fragment 7Q5," New Testament Textual Research Update 2 (1994) 94-98.

${ }_{12}$ Puech, "Des fragments grecs," 573-77.

${ }_{13}$ This was the case in my reconstruction of a Bodleian fragment of Exod. 9:1-14; cf. M.V. Spottomo and N. Fernández Marcos, "Nuevos fragmentos del Exodo griego (Ms. Gr. Bibl. f. 4 [P])", Emerita 44 (1976) 385-95: in v. 7 (col. 2 v. Ell 11-12) the (Ms. Gr. Bill. f. 4 [P])" Enerita 44 (1976) 385-95: in $v .7$ (col. 2 v., ll. 11-12) the

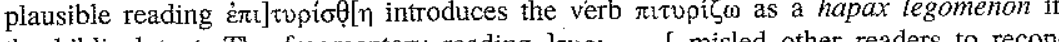
the biblical text. The fragmentary reading ] $v 0 \rho \mathrm{fl} .$. [ misled other readers to reconstruct $\mu \alpha . \rho]$ ruplov, without meaning in its context.
5 , and the small trace of the $\alpha$ proposed by the editio princeps $s^{14}$ and É. Puech ${ }^{15}$ after $\tau \omega \mathrm{r}$ in line 2 together with the $\alpha$ of $\alpha \alpha \mathrm{t}$ in line 3.

In order to establish the accurate shape of ambiguous letters, several samples are necessary. For that reason single letters, the $\gamma, \tau$ or $v$ in line 2 , and the $\pi$ in line 3 , cannot be unhesitatingly confirmed. After $\kappa \alpha \mathrm{r}$ in line $3 \tau \omega / \tau$ o is likely, but a $\pi$ is also possible. ${ }^{16}$ In line 5 , any round letter could appear at each side of the $\eta$. One can also see a trace of ink at the right end.

Full words are important for the correct interpretation of the letters. In this fragment the absence of words of any significance is a definite handicap: koi is the only word, very unhelpful indeed. ${ }^{17}$

\section{Philological questions}

Although the following textual considerations may appear quite obvious, they will be helpful for understanding what follows.

If the text of a critical edition does not fit into a regular stichometric order-as is the case in every identification of 7Q5-two possibilities must be accepted: 1) irregularities in the margins and script, ${ }^{18}$ 2) variant readings in the restored text.

${ }^{14}$ M. Baillet, J.T. Milik, R. de Vaux, Les "petites grottes" de Qumrân: Textes (Oxford: Oxford University Press, 1962) 142-46. The J.K. Elliott "Note on multispectral imaging," in New Testament Textual Research Update 2 (1994) 98, is very suggestive; are $7 \mathrm{Q}$ fragments awaiting their turn?

${ }^{15}$ É. Puech, "Des fragments"grecs," 575: "... la lecture de la séquence I A[ rend parfaitement compte de tous les traits visibles, y compris de la distance entre les mots. Elle seule s'impose sans dis

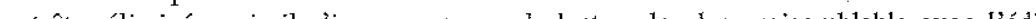
peut être éliminé, mais il s impose comme la lecture la plus vraisemblable avec l'édition... alors qu'un $\mathrm{N}$ est totalement impossible et ne peut en rien être qualifié de "lettre mutilée'."

${ }^{16}$ K. Aland, "Neue neutestamentliche Papyri III," NTS 20 (1974) 375, also accepts a $\pi$.

${ }^{17}$ O'Callaghan in his argumentation forgets about the wide use of that particle at the beginning of a sentence in the Old Testament, suggesting it as a distinctive characteristic of Mark: "And if it is considered that in Mark more than ninety per cent of the pericopes begin with 'kai', showing a 'very vulgar Greek-which it must be also said is characteristic of Mark's Gospel-, the arguments in favour of that identification said is characteristic of Mark's Gospel-, the arguments in favour of that identification
are increasing" ("Y si se tiene en cuenta que en Marcos más del $90 \%$ de las pericopas empiezan por 'kai', mostrando un griego muy vulgar-que también hay que decir que es propio del Evangelio de Marcos-, los argumentos en favor de la identificación aumentar:") (Internet 13). A random sample: all the paragraphs in 2 Chronicles from chapters 9 to 13 begin with koí, and a great number of other sentences are introduced by кoí; cf. A. Rahlfs (ed.), Septuaginta (Stuttgart: Privilegierte Wurttembergische Bibelanstalt, 1949

${ }^{18}$ See E.G. Turner, Greek Manuscripts of the Ancient World (Oxford: Oxford University Press, 1971) nos 55 and 56 (middle first century BCE), that show a remarkable lack of evenness at the end of the lines, plus a reduction in the size of the letters. 
Since all the manuscripts present some or many unique readings it would also be acceptable to introduce into the reconstruction of the text, a variant reading, even if it is not supported by any of the extant witnesses. ${ }^{19}$

A further hypothetical possibility is to consider the fragment as part of an unsalvaged literary work (only a small part of what has been written in Antiquity hàs been preserved), or of a private document: contract, receipt, or letter. In these cases the restoration of very little material is pointless. The insignificance (in every sense of the word) of this fragment and the palaeographic problems will never permit any identification to become definitive.

\section{Related problems}

Other particulars underscore the difficulties of accepting the identification of 7Q5 with two verses of the New Testament.

The early date of the handwriting (first century $\mathrm{BCE}$ ) presents a clear problem. ${ }^{20}$ Although a fifty year margin is admitted, it is not reasonable to stretch the date up to $50 \mathrm{CE}$.

J.A. Fitzmyer brings up certain questions about the lack of evidence for how and when the fragments reached the cave. ${ }^{21}$

7 Q5 leaves us with an open forum for a whole realm of possibilities. Yet, palaeographical, philological, and historical reasons do not provide us with any objective support for its equivalence to Mark 6:52-53. Thiede and O'Callaghan go too far when they equate their hypothesis with truth, and categorically exclude any other proposals. ${ }^{22}$

${ }^{19}$ This is the case of the omission of Ė

${ }^{20}$ More precisely in the second half. I. Gallo, Greek and Latin Papyrology (London: University of London, 1986) 85, places the style with serifs in "late second/first century BCE." A $\tau$ in line 2 colid advance the date to the second century BCE, and if an $v$ is read, the date of the fragment could hardly be placed in the first century CE an $v$ is read, the date of the fragment $c 0$
in which a deep roman $v$ is in full use,

in which a deep roman $v$ is in full use,
21 When J.A. Fitzmyer reviews J. O'Callaghan, Los primeros testimonios del Nuevo Testamento, Bib 77 (1996) 576, his opinions support the position of those many scholars who wish to stop O'Callaghan and Thiede's bias of going beyond the evidence.

${ }^{22} \mathrm{O}^{\prime}$ Callaghan suggests that this debate follows ideological trends: to the question "Don't you see at the bottom of this matter a discussion between different preconceptions of exegtic thought?" he answers, "It would seem so. There is a background

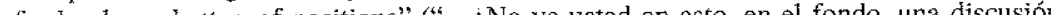
entre preconcepciones de pensamiento exegético?-Pues parecería que sí. Aquí hay un trasfondo de escuelas o mejor de posiciones"), (Internet 13-14); and on p. 9: "if this papyrus were from the 7th century, it would be fantastic, but, it is from the 1st century, and for that reason it is not accepted. And I only understand these reservations
The fragment does not provide enough evidence to support: 1) one exclusive identification, 2) innovations in the history of the text, ${ }^{23} 3$ ) the sweeping propaganda spread by O'Callaghan and Thiede, otherwise very effective in a non-specialized world; scholars demand more thorough proofs. Even the analysis of mathematical probabilities, adduced by O'Callaghan as the most convincing evidence, is not a reliable method. ${ }^{24}$

for the consequences that come with its acceptance" ("Si este papiro fuera del siglo VII, sería fantástico, pero claro, es del siglo I y por ello no se acepta. Y yo sólo comprendo estas reservas por las consecuencias que trae esa aceptación"). It seems that he assumes certain scientific dishonesty in those who do not agree with him. I wonder if the one responsible for deriving ideo might display a more balanced and scientific appreciation of things against thejr own prejudices" ("Que frente a sus prejuicios hagan gala de una más ecuánime y científica apreciación de las cosas") (Internet 14). Before the ideological ingredient came to dominate the core of discussion, C.J. Hemer wrote a note "7Q5: A Correction," SPap 16 (1977) $39-40$, two pages that might easily be embraced by most scholars.

${ }^{23}$ J.K. Elliott deeply criticizes Thiede's exposition in reviewing C.P. Thiede and M. d'Ancona, The Jesus Papyrus (London: Weidenfeld \& Nicolson 1996), NovT 38 (1996) 393-99: "Whatever the [Dead Sea] Scrolls may reveal, it is universally recognised that they tell us absolutely nothing about the origins of the NT Gospels!" (p. 393), and "It is irresponsible to proceed from an ill-founded and generally unac(p. 393), and "It is irresponsible to proceed from an ill-founded and generally unac-
cepted redating of one MS. to argue that the dates of composition of the canonical Gospels themselves need to be similarly revised" (p. 394). He also points out other disfavourable elements (carelessness, incompetence, falsity, hostile attitude toward opponents, etc.), in contrast with G. Stanton's Gospel Truth? New Light on Jesus and the Gospels (London: HarperCollins, 1995): "Stanton's is a cautious, readable exposition of the consensus views about NT Gospel criticism. His judgements are sensible, sensitive, and carefully

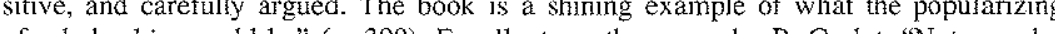
of scholurship would be" ( $p$. 39 ). Excellent are the pages by P. Grin, "Note sur les propositions du Pr Carsten Peter Thiede," $R B 102$ (1995) 589-91, in which he raises his objections to Thiede's exaggerated conclusions about the origins of the Gospels.

${ }^{24}$ The full description of this analysis is in the epilogue to O'Callaghan's Los primeros testimonios, 116-39, written by A. Dou. The problem is not one of the mathematical structures, but of the texts. Which texts are included in that Corpus Graecum and how they are presented. "Let us call Corpus Graecum the bulk of the literature Apocyphal and Patistic literates, whin, fhrhernore, has been preserved up to now and collected either in a number of written volumes or in the memory of a computer" ("Llamemos Corpus Graecum al conjunto de toda la literatura escrita en griego y anterior al final del siglo I d. C.; o sea, incluyendo las literaturas clásica, béblica, apócrifá y patrística; además, que se haya conservado hasta hoy día, y se encuentre toda ella recopilada sea por escrito en un conjunto de volúmenes o en la memoria de un ordenador") (ibid. 117). I doubt that all the manuscript evidence of biblical and Apocryphal literature was present in that Corpus" of. E. Utrich, "A Greek Paraphrase of Exodus on Papyrus from Qumran Ca P. Papt for 294-97; the first paragraph of the Conclusion illustrates the actual restrictive character 


\section{Alternatives ${ }^{25}$}

It is sufficiently demonstrated that an exclusive identification of 7 Q5 with Mark 6:52-53 is untenable. It is also demonstrated that any identification is at best unreliable; notwithstanding, in order to respond to O'Callaghan's "call for papers,"

- Beginning the column: ${ }^{28}$

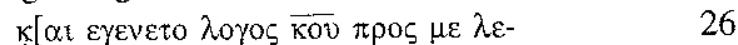

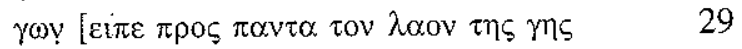

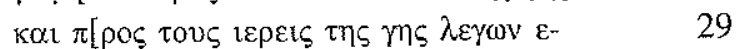

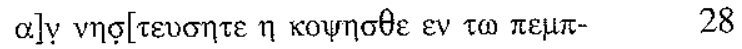

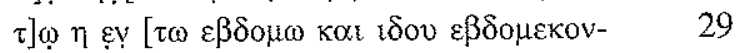

- Within the column:

$v \alpha \varepsilon \tau] n[$ [Kol $\varepsilon \gamma \varepsilon v \varepsilon \tau o ~ \lambda o \gamma o \varsigma \overline{\kappa o v} \pi \rho \circ \varsigma$

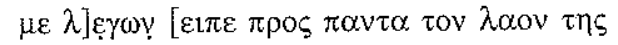

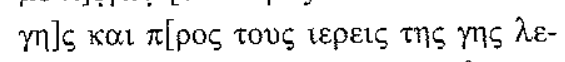

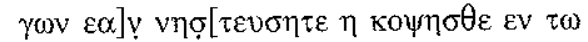

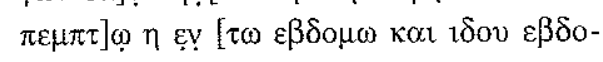

27

30

28

28

28

- Centered in the column:

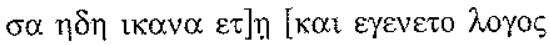

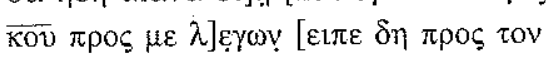

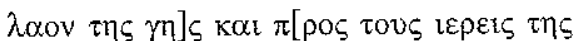

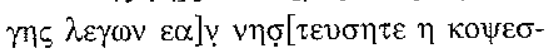

$\theta \varepsilon \varepsilon \nu \tau \omega \pi \varepsilon \mu \pi \tau] \omega \eta \varepsilon \vee[\tau \omega \varepsilon \beta \delta \rho \mu \omega \kappa \alpha \tau$

of that kind of search (p. 298). See also G.D. Fee, "Some Dissenting Notes on 7Q5 = Mark 6:52-53," JBL 92 (1973) 112.

${ }^{25}$ I refer to the infrared photograph published by O'Callaghan in several instances (e.g., Bib 53 [1972] 521). The photograph in the Epílogo of his book Los primeros testimonios del Nuevo Testamento is especially good. I doubt the original could be more

timonios

${ }_{26}$ "I have always said, from the very beginning, that if someone proves to me that this is not from Mark's Gospel, I will promptly accept it. But..." ("Siempre he dicho, desde el comienzo, que si a mí me prueban que esto no es del Evangelio de S. Marcos, yo lo acepto en seguida. Pero ...") (Internet 6). The point is that he considers Mark's identification as the pattern; obviously other readings of the papyrus do not coincide with it (they would be Mark 6:52-53), therefore, as differing from the pattern, O'Callaghan holds that they must be rejected.

27 accept that the stichometry is to be improved from my first edition (Sefarad 52 [1992]).

${ }^{28}$ In order to give more formal possibilities (my intention is far from making a mess of this question), I present a text that may appear to be the beginning of a column; consequently the space before kol would correspond to the margin between columns,

The second reconstruction seems best to me.

The text is that of Zech. $7: 3 \mathrm{c}-5 .^{29}$ Following O'Callaghan's own words, ${ }^{30}$ I submit the following difficulties and possible alternatives: Line 1:

The horizontal stroke could belong to an $\eta$.

Line 2:

Here the only visible syllable presents problems. Although Thiede says that "the tau is above suspicion" and the existence of a $n u$ is "proved... beyond the shadow of a doubt," ble could be read $\gamma \omega t, \tau \omega \mathrm{r}, v \omega \mathrm{r}$; or $\gamma \omega v, \tau \omega v, v \omega v ;{ }^{32}$

For the first letter a $\gamma$ is suitable for my case. ${ }^{33}$ Although for many scholars a $\tau$ seems to be clear, I cannot accept that proposal because such a movement of the hand is not usual for a $\tau . .^{34}$ Contrasting that letter with the $\pi$ in line $3(\tau$ if $\mathrm{read} \tau \mathrm{\tau} / \tau \mathrm{o} / \tau \omega)$, the horizontal stroke would probably have been drawn longer to the right side. This first letter seems to be drawn in one movement from left to right and down

and the dots to the left of line 2 could be the rest of a longer line in the preceding column (cf. Turner, Greek Manuscripts, no 51 [325-275 BCE] and, more clearly, no. 72 [third century CE]), or traces of a marginal sign.

29 O'Callaghan says that the reconstruction of Zech. $7: 3 \mathrm{c}-5$ is not the very text, but a paraphrase of Zechariah (Internet 6). Actually, it does not reproduce the edition (no manuscript is the text of an eclectic edition), but all its readings are witnessed by a manuscript tradition; cf. the critical apparatus of J. Ziegler (ed.), Septuaginta Vetus Testamentum Graecum XIII: Duodecim Prophetae (Göttingen: Vandenhoeck \& Ruprecht, 1967) ad loc. This has been criticized by Thiede, "Greek Qumran Fragment," 397-98, and by O'Callaghan, Los primeros testimonios, 114; their reluctance to accept a text that does not fit into $a$ concrete recension may fade if they had considered that no manuscipt is fully adapted to a recennion, since recensions are not identically fol20 705 does not provide enough material to be classified within any of the already known recensions; it can only be said that its readings are all supported by manuscript evidence of the text of Zechariah.

${ }_{30}$ "It is evident that in the discrepancies... the alternative letters must be scientifically explained" ("Es evidente que en los puntos de disconformidad... los cambios de letras que se observan puedan científicamente explicarse"); $c$. J. O'Callaghan, "7Q5: Nuevas consideraciones," SPap 16 (1977) 41, answering Hemer (cf. supra n. 23).

31 Thiede, "Greek Qumran Fragment," 396.

32 About the v, I have no views since-I have not checked the original. At first glance I agree with G.D. Fee ("Some dissenting notes," 110) and É. Puech ("Des fragments grecs," 573-76) reading i, but $O^{\prime C}$ allaghan's arguments for a $v$ also seem to be possible.

${ }^{33}$ A $\gamma$ with a long stroke to the left side needs to be justified: there are some examples in E.G. Turner, Greek Manuscripts: no. 55 (middle first century BCE), col. iii,

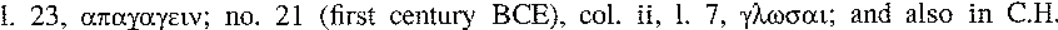
Roberts, Greek Literary Hands: 350 B.C.A.D. 400 (Oxford: Oxford University Press,

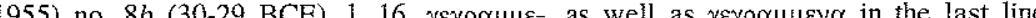
Certainly some other examples would testify that a $\gamma$ with such form is not impossible.

${ }^{34}$ It goes on a cursive $\tau$ of the second century $\mathrm{BCE}$.
. 
with a serif to the left and a slight loop at the top right. Apart from the context, it seems to be an v; it suits more properly the ductus of the letter. ${ }^{35}$

If an $t$ is read at the end of the syllable, the letter that follows could be a $\lambda$ or perhaps an $\alpha .^{36}$

About the controversial v, I would agree with Puech in denying it if my text would have been provided with an $\mathrm{t}$, but unfortunately it has not.

The difficulties presented in line 2 reinforce the sound principle of avoiding a definitive reading of a fragment which contains ambiguous characters, especially when such characters do not have clear evidence indicating the word they belong to.

Line 3:

I argue for a $\pi$ after $\kappa \alpha$. One can see the slope to the right of the second vertical stroke which confirms a $\pi$ of the same type as the $\eta$ in line 5.37

The space before $\kappa o t$ is justified either by the margin between columns (in that possibility), or as a reading handed down by the Masoretic tradition (such a reading would present a disjunctive accent, a zaqef qaton, on the preceding word), or can simply be explained as the use of the scribe. The minimal material of this papyrus does not provide the comparative examples needed for reliable interpretation. Line 4:

The slight separation between both of the $v$, while the second one is linked to the following $\eta$, argues in favour of placing each one in a different word (

${ }^{35}$ Cf. F.G. Kenyon, The Palaeography of Greek Papyri (Oxford: Clarendon Press, 1899): table of alphabets on p. 129; plate XII (the Louvre Hyperides, second century

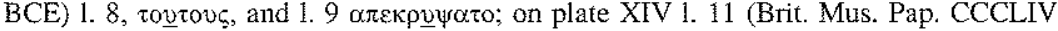
ca. $10 \mathrm{BCE}, 1.12$ ) $\tau o v$, where the $v$ is less depressed than the $\tau$. Other examples of that $v$ written in one movement of the hand can be found in B.P. Grenfell and A.S. Hunt, The Oxylhinchus Papyri, Part I (London: Eeypt Explotation Fund 1898) p.S. and Turner, Greek Manuscripts, no. 67 (first/second CE). Reading an v in 7Q5 requires a new interpretation of the whole (one should think of the end of a form in -v $v$ or $-v$ or a verb in $-v \omega$ or $-\varepsilon v(\omega)$, then the possibility of beginning a line appears remote.

${ }_{36}$ The irregularities observed in the handwriting of this fragment make an $\alpha$ possible, notwithstanding the fact that the stroke does not match the other $\alpha$ in the text.

${ }^{37}$ Arguments against $O^{\prime}$ Callaghan's reading $\tau t$ for $\delta 1$ are convincingly expressed by M-É . Boismard in "À propos de 705 et Mc 6.52-53" RB 102 (1995) 586. He points

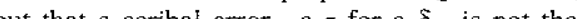
by $\mathrm{O}^{\prime} \mathrm{Callaghan}$ in support of his reading. Those changes, common in papyri, rarely come in biblical texts.
Line 5:

Only an $\eta$ is clear.

Although Puech proposes a $\theta$ before the $\eta$, the papyrus is sufficiently damaged that to propose an $\omega$ with long arms is not out of the question.

The letter following the $\eta$ very likely seems to me an $\varepsilon$.

The upper stroke that follows, in my view, is a serif of a $v$.

\section{Further alternatives}

Other possibilities for $7 \mathrm{Q} 5$ have to do with the Apocrypha or Parabiblical literature. In this connection, I present a new reading of the fragment with specific explanations for each of my hypotheses.

In my research I had to take into consideration that concordances, which are based upon the edited texts, rarely include variant readings; consequently, the search becomes unfruitful when the key words are attested by the part of the manuscript tradition that appears only in critical apparatuses. ${ }^{38}$ Also, critical editions of the Apocrypha are not yet complete; extant manuscripts are quite diverse and their various readings are not easily accessible. The Greek Enoch in particular has been preserved in only two large portions, the sixth century Gizeh Fragment and the fourth century Chester Beatty Papyrus. ${ }^{39}$ Some fragments also exist in the work of Georgius Syncellus (d. ca. 810), whose free version has been "claimed as a more reliable representative, both as to text and order, of the original." 40 The carelessness evidenced by the Gizeh Fragment and the great differences between the manuscripts of Enoch argue for the legitimacy of proposing a reconstructed version of this passage, which I have done.

In connection with the identifications made by some scholars of other fragments from Cave 7 as the Greek Enoch, ${ }^{41}$ I propose another possibility for 7Q5. Conjectures are introduced on the basis of the textual plurality (highly confirmed in the transmission of that literature), and on the chronological and cultural environment of 7Q5. These considerations make it much more likely that 7 Q5 is to be placed among

${ }^{3} 8$ Has A. Dou operated with all the witnesses in his mathematical analysis? (cf. supra n. 24).

${ }^{39}$ M. Black, Apocalypsis Henochi Graece (Leiden: E.J. Brill, 1970) 7.

${ }^{40}$ Ibid. p. 8.

41 7Q4 = Enoch 103:3-4 and 7Q8 = Enoch 103:7-8; cf. G.-W. Nebe, "7Q4-Möglichkeit und Grenze einer Identifikation," Rev $Q 13$ (1988) 629-33. 
the witnesses of the Old Testament or the Apocrypha rather than assigned to the New Testament. ${ }^{42}$

My new identification can be explained as follows:

\section{Enoch 15:9d-10:}

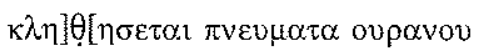

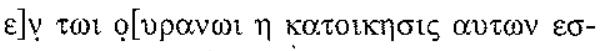

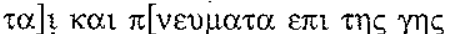

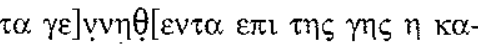

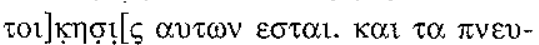

The text ${ }^{43}$ has been altered in line 3 by the omission of $\tau \alpha$ after $x \alpha$;

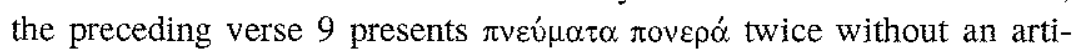
cle, which can justify the presumed omission. ${ }^{44}$

It is palaeographically impossible to read an 0 in line 2 and a $\kappa$ in line 5. A solution for the 0 would be the substitution of $\alpha v \omega \tau \varepsilon \rho \omega$ for oúpovê (twice in Enoch 14:17 and 15:9). For the $\kappa$ in line 5, I suggest $\eta$ kó $\theta$ nis (twice in Jeremiah, although non-existent in the Apocrypha)

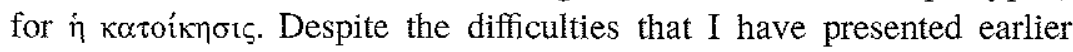
concerning the reading of $\tau \omega \mathrm{t}$ in line 2 , it is a widely accepted possibility for many scholars.

The resulting text, although hypothetical, is not impossible:

\footnotetext{
42 As it is likely that the 70 fragments come from the milieu of Qumran, the Septuagint and the Book of Enoch, or related Greek literature, are the limits to the possibilities. Since the fragments are from different hands, it seems quite impossible that they should belong to different scrolls of different books of the New Testament, as $\mathrm{O}^{\prime}$ Callaghan claims in support of 7Q5 = Mark 6:52-53. A New Testament library is obviously not expected to be found in Qumran; this is why different scholars have identified the 7Q fragments with non-New Testament texts: $7 \mathrm{Q1}=$ Exod. $28: 4-6,7 ; 7 \mathrm{Q} 2=$ Ep.Jer. 43-44; 7Q4 = Num. 14:23-24, Job 34:12-15, and Enoch 103:3-4; 7Q5 = 2 Sam. 4:125:1 and 5:13-14; Zech. 7:3c-5, and Enoch 15:9-10; 706 frag. $1=$ Ps. 9:32, 34:28, 50:17-18, and Prov. 7:12-13; 7Q6 frog. 2 = Is 18:2; 708 = Zech. 8:8-9, and Enoch Qoh. 6:3, etc.); other identifications (except for 7Q5)' in A.C. Urban, "Observaciones sobre ciertos papiros de la cueva 7 de Qumran," RevQ 8 (1973) 233-51.

From the "Corpus des textes" in A.-M. Denis, Concordance grecque des Pseudépigraphes d'Ancien Testament (Louvain-la-Neuve: Université Catholique de Louvain, 1987) 821. This passage is witnessed only by the Gizeh fragment; although it is also in the Syncellus's version, the text is extremely reduced in verse 10 and does not provide alternative readings; cf. M. Black, Apocalypsis, 30 .

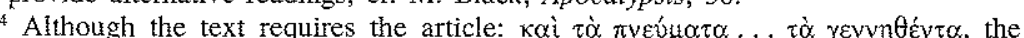
omission is acceptable. The dissimilar use of the article in $v .9, \dot{\eta} \dot{\alpha} \rho x \eta े$

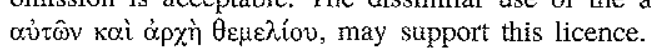

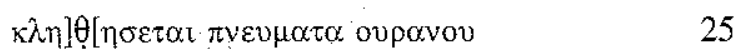

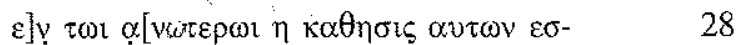

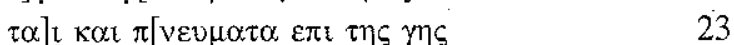

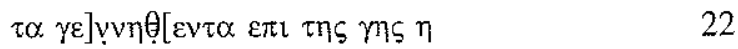

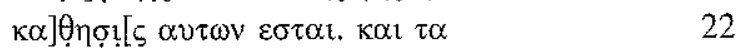

\section{Conclusion}

It is possible that 7Q5 is neither part of Zech. 7:3c-5 nor of Enoch $15: 9 \mathrm{~d}-10$, but can it be said that it is part of Mark 6:52-53 without doubt? Certainly not. The exclusive identification of 7Q5 with Mark 6:52-53 appears to fade away with the possibilities offered by the text of Zechariah, which bears the same or fewer papyrological problems and is culturally and chronologically more feasible. ${ }^{45}$ Even the text of Enoch, with its difficulties, is more plausible because it fits in better with the society and cultural milieu of Qumran. ${ }^{46}$ Historical evidence together with the concrete and measurable witnesses at our disposal should set the limits on uncontrolled scholarly creativity. It is my hope that recent and less recent studies that "successfully demolish O'Callaghan's claim" ${ }^{\prime 47}$ will cause us to seriously doubt that $7 \mathrm{Q} 5=$ Mark 6:52-53.

\footnotetext{
${ }^{45}$ The enthusiastic relief after a long and hard papyrological labour does not justify uncritical positions; cf. Spottorno, "Pequeños fragmentos," 337: "[O'Callaghan] fully accepted some papyrological concessions in texts from the New Testament, that perhaps would not have passed his scientific analysis, if they had been from the Old haps would not have passed his scientific analysis, if they had been from the Old
Testament" ("aprobó plenamente en los textos neotestamentarios algunas concesiones papirológicas que, de haber sido en textos veterotestamentarios, quizá no habrían pasado por el tamiz de su análisis científico").

4 Cf. Nebe, "7Q4-Möglichkeit," 633.

${ }^{47} \mathrm{~J}$. Fitzmyer review in Bib 77 , p. 576 , in reference to various articles that appeared in $R B 102(1995)$.
} 